\title{
English-French Translation of Igbo Traditional Marriage Items: A Semiotic Approach
}

\section{Asadu Oluchukwu Felicia Ph.D}

\author{
Department of Modern European Languages, Nnamdi Azikiwe University, Awka, Anambra State,Nigeria \\ Email: asaduoluchukwu@yahoo.com
}

\section{Doi:10.5901/mjss.2016.v7n1s1p311}

\begin{abstract}
Culture is the people's way of life including their beliefs and customs. Traditional marriage in lgbo land is symbolic because it reflects the Igbo man's ideology and idiosyncrasies This could be seen in the different gift items brought by the bridegroom to the family of the bride before the bride's kindred officially and socially legalize the marriage The items differ slightly from one locality to another and from one Igbo community to another. These cultural items that must be presented on the day of one's traditional marriage( otherwise called 'igba nkwu nwanyi 'okuko onye uwa or igbu ewu nna) by the groom are quiet elaborate and very significant. It is a must in Igbo land that any man who seeks the hand of an Igbo lady in marriage must concur to the provision of such items as they are listed. Alternatively, he could give the money equivalent of the items. The thrust of this paper is to translate the frequently listed items from English to French, analyze them and ex-ray their significance and meaning as they are given and received. The paper also investigates the various stages of traditional marriage in Igbo land precisely in Anambra State.
\end{abstract}

Keywords: Igbo culture, Igba Nkwu, Semiotics, Anambra State

\section{Introduction}

In African societies, the primary aim of marriage is for procreation. Globally, marriage is seen as a social contract between a man and a woman who have agreed to live together permanently as husband and wife. Thompson and Hickey (2008:359) see marriage as "a legally recognized economic and sexual relationship between two or more persons that include mutual right and obligations and is assumed to be permanent".

Worthy of note is that the Igbo only recognize a marriage between a man and a woman; other forms like gay marriage man with animals are seen as taboo. Traditional marriage involves relations, friends and well wishers who are all invited to the bride's place. It is the climax of the union between the couple. It symbolizes that the man and woman are now husband and wife under the native law and custom of the people.

Marriage is the bedrock of every Igbo community. It is a way of showing that a man is responsible and has come of age to shoulder responsibilities. According to Mbiti (1975:108) "marriage is an essential obligation that legitimizes an adult into the community". In the same vein, Charles (2010:246) says: "in Africa, marriage occupies a unique place in human life cycle. It is the pivot of human continuity an attested acid for maturity..." Marriage can be seen as the salt of the society, the basis for procreation, a tool for social affinity, togetherness peace and love. Marriage is celebrated in African society especially in Igbo land with gift items some of which signify welcome, happiness, sweetness and bitterness.

\section{Methodology of the Study}

Three different local governments in Anambra State were randomly selected for this study and the researcher interviewed some of the elders from these Local Governments. The researcher used qualitative method of asking, observing and interviewing people The three towns from the three Local Governments are Amawbia, a neighboring town which shares a boundary with Awka town; Awka is the capital of Anambra State: Enuguagidi, a town in Njikoka Local Government, Uga in Aguata Local Government. The researcher itemized the gift items and translated them into French. The significance of such gift items was also identified.

\section{Theoretical Frame Work}

This study is based on two theories namely semiotic theory and Dynamic Equivalence. Notably among semioticians are 
Charles Sanders Pierce, an Anglo-American and Ferdinand Saussure, a Swiss-French. Other semioticians include Noam Chomsky, Umberto Eco, R. Barthes and Jean Baudrillard. Semiotics is the theory of creating and interpreting meaning. In a nutshell, semiotics is the study of signs. Saussure idea of semiotics is divided into two and these are the signifier which is the meaning and the signified which is the understandable part of the sign. On the other hand Pierce's semiotics is divided into three namely sign, object, interpretant. Signs could be verbal or non- verbal and they could mean anything imaginable; an object is the topic of the sign whereas an interpretant is the meaning attached to the sign or the mental representation of the sign. The sign represents the object or the referent in the mind of an interpreter. Utwente (2014: 20) states that "social semiotics examines semiotic practices specific to culture and community for the making of various kinds of texts and meaning in various situational context and context of culturally meaningful activity". Thus social semiotics will be used in interpretation of the marriage gift items. In translating the gift items, Nida \& Taber's Dynamic Equivalence will be employed. Dynamic Equivalence according to Nida \& Taber (1969:70) "is the quality of a translation in which the message of the original text has been transported into the receptor language that the response of the receptor is essentially like that of the original receptors." In essence, Dynamic Equivalence lays emphasis on the meaning of words of a text as opposed to Formal Equivalence which emphasizes on the fidelity to lexical details and grammatical structure of the language. Nida and Taber's Dynamic Equivalence is of similar temperament with the theory of meaning propounded by Danica and Lederer. Translation of cultural items falls under Literary translation.

Nida(1964:24) said:

Because translating always involves communication within the context of interpersonal relations, the model for such activity must be a communication model, and principles must be primarily sociolinguistic in the broad sense of the term. As such, translating becomes a part of the even broader field of anthropological semiotics.

This shows that a translator must take into cognizance the cultural and sociocultural elements that occur in a text each time one translates. Furthermore Hoof (1989:11) opines that:

Traduire, c'est peser, c'est comparer, c'est confronter deux systemes linguistiques, deux syntaxes, deux structures, mais aussi deux génies deux conceptions de la vie...C'est commerce intime avec la vie.

Translate is to weigh, to compare, to examine two linguistics systems, two syntax, two structures but also two genie, two conceptions of life... It is an intimate relationship with life.(our translation)

Goncharenko(1981:71) has the same opinion with Hoof when he says:

Le traducteur littéraire doit se pencher sur trois péripétes (un trépied) a savoir: la sémantique (ce qui est dit), la stylistique (comment cela se dit), et la perspective pragmatique (pourquoi cela se dit et la reaction evoquée sur le locuteur ou le lecteur)

A literary translator must stand on three conceptualisations ( a tripod) namely: semantics (what is said) ;Stylistics ( emotional effect of what is said) and the pratical perspectives / targets( why what was said was said and the reactions evoke on the speaker and the reader.) (Our translation)

In a nutshell literary language is connotative with different shades of semantics and interpretations which makes translation of literary texts more cumbersome than translation of scientific or pragmatics texts.

\section{The Igbo}

The Igbo speaking communities are found in the South East of Nigeria. The communities comprise five states out of the thirty six states that make up Nigeria. The Igbo are found in Abia, Anambra, Ebonyi, Enugu, Imo and also a large part of Delta state. Igbo language is one of the eight major languages spoken in Benue Congo or the kwa group. It is one of the three major languages in Nigeria. According to Onwuejeogwu

The Igbo cultured area is an area running outside the settlements of Agbor, Kwale, Obiarukwu, Ebu (West Niger area) Ahoda, Diobu, Umuagbayi, (Port Harcourt Area) and Enugu Ezike (Nsukka area) and Nzam. The imaginary line encloses an area in which the people not only speak the lgbo language but share typical and significant culture traits and patterns up to or above $50 \%$. 


\subsection{Types of Nigerian marriages}

Three types of marriages are practiced in Nigeria namely: traditional, religious marriage (church/mosque) and the civil marriage. Among all the three marriages, the traditional marriage precedes and supersedes all others because the parents of the bride have to give out their daughter to a groom before they would become husband and wife after which they can proceed to perform either court marriage or religious marriage depending on their fate.

\subsubsection{Igbo traditional Marriage}

Marriage in Igbo land is done in stages. The first stage is called iju ase which means the inquiry. Inquiries are made by both families to find out whether there is perennial disease like epilepsy or madness in the linage of the man or woman. Inquiry is also made to ascertain whether the families have good background. Marriage fact - finding regarding the would-be spouse as well as the family history if accepted, the concerned families will now proceed to another stage which is called iku aka n' uzo, first visit also called first introduction. ( formal acquaintance)

The bridegroom, accompanied by his father and one or two relations will then go to the house of the intended bride's parents to inform them that they are asking for their daughter's hand in marriage. This is done in Amawbia with four kola nuts and a bottle of hot drink. This is to ascertain whether the girl in question is single. If yes is she going to accept the groom as her suitor? Then the bride's family will ask them to go and come back again. The bride's people will ask questions about the intended family such as what the groom does for a living .It is after these questions must have been satisfactorily answered that the bride's father may now tell the family of the suitor that their door is now open to them This will lead to the second stage of introduction.

\subsubsection{The second stage of introduction}

A day is set for the second introduction. The groom's family will go with four kola nuts (depending on the town) with a bottle of hot drink. The groom is accompanied by his farther. The bride's family gathers members of their extended family. After the breaking of kola nut, the groom's family is invited to announce what brought them. After that, a date is set for the payment of bride price and dowry. On the day of the payment of the bride price otherwise called ime ego nwaanyi, it is only the bride's inner family that is needed, same goes to the groom. The bride's family will gather dry sticks and break them to represent particular money denomination. The Igbo believe that they do not sell their daughters. When the two families must have unanimously agreed and the bride price paid, ,they come out rejoicing, The kola nut is now broken to be eaten and drinks are shared The Igbo then says that they saw a female cow which they want to collect or that they saw a maiden, whom they cherish. So they came to confirm if it is possible to ask for her hand in marriage. Then, it will be the turn of the bride's family to tell them, that they have so many maidens in their family; which one? The name of the girl is then mentioned.

The father will be asked by his kinsmen to summon his daughter. When she comes, the oldest among the kinsmen, who has been moderating the affair, will tell her that some people have come to ask for her hand in marriage. She will be given a glass filled with palm wine. The old man will tell her to take a sip and give to the man (husband to be). It is after she must have had a sip of the wine and given to her husband that other things will follow. This shows that she has accepted the man, if she does not sip and give it to the man, it means that she has rejected the suitor. In this case nobody will drink the wine and the ceremony will be closed. After the drinking of the palm wine, the bride will go back to her mother's room. This is where she will be until the entire ceremony is over. It is only after that, that the discussion about the payment of the bride will commence. Where the bride price is being paid, the father of the bride cannot say anything about the amount. He definitely is present in the gathering, but not heard. In ancient time, there was no stipulated amount. It is only negotiated between the two families. Recently like in Amawbia traditional set-up where this author comes from, bride price for is N1000. The bride's mother has no say with regards to the amount the groom's family will give to her for the up keep of her daughter In most cases, it is what the suitor wants that he will give to the mother of the bride. N200 will be returned to them. (To the groom's family). This is to show that the Igbo do not sell their daughters. The money paid as the bride's price or dowry will not be given to the bride's father but rather, to the oldest man among them. The jars of palm wine are left behind purposely for another ceremony, which is called isenete ihe nwaanyi

First contact of the bride with the groom's family :\{lsenete ihe nwaanyi\}

The return of the palm wine jars to the groom's kinsmen. Generally, this ceremony is not an elaborate one, but it is intended to introduce the new wife to the husband's family or to the village. During this ceremony, the bride and her escort are lavishly entertained, after which she returns to her father's house after staying in the groom's family for four 
days. Before she leaves, she will be taken around her husband's village to share cream and soap to her fellow wives or mates. This is done so that here fellow wives will know her and so that they can get to know one another. After that she goes home, back to her father 's house. This will enable the bride to know whether she can continue with the marriage or not .If she comes back and says she is no longer interested in the marriage her father will have to return the dowry to the groom's family.

\subsubsection{The final ceremony lgba nkwu nwanyi, okuko onye uwa or igbu ewu nna}

This ceremony is quite elaborate, and it is held in the bride's home. During this event, the groom will come along with his kinsmen and women, and go to the bride's father with the following gift items. The guests are entertained lavishly with pounded yam and well prepared soup. Assorted dishes and drinks are prepared for one to choose from or eat all if one can. The same applies to drinks. The real marriage which must be witnessed by selected members of the two families is now conducted before the public, in the bride's compound where, after the blessing of kola nut and pouring of drinks, fowls are slathered, the slaughtered; this will be used to prepare delicious soup or yam porridge to be eaten by the two families. This ceremony is known as the main marriage contract witnessed by the extended family. It is worthy of note that in Awka town without this particular ceremony, any child that comes from the union belongs to the girl's family and will never bear the surname of that man. After they have been entertained lavishly, the eldest man from the bride's family will take the bride's hand and hand her over to the eldest man from the groom's family who in turn will hand the bride's hand to her father in law. The couple will then kneel before the bride's father for final blessings after which they will leave their in laws house with their wife to her husband's house.

Data Presentation: the table below shows the items required by the three towns from three different Local Governments in Anambra State for traditional marriage.

Group A: Items for Kindred Men

\begin{tabular}{|l|l|l|l|}
\hline & Uga & Amawbia & Enugu Agidi \\
\hline 1 & $\begin{array}{l}21 \text { gallons of palm wine } \\
105 \text { litres de palme de vin }\end{array}$ & $\begin{array}{l}19 \text { gallons of palm wine } \\
95 \text { litres de vin de Palme }\end{array}$ & $\begin{array}{l}\text { 20 gallons of palm wine } \\
\text { un bidon de vingt litres }\end{array}$ \\
\hline 2 & $\begin{array}{l}\text { A big fowl \& N50 to Kill it (un gros coq et } \\
\text { cinquante naira }\end{array}$ & $\begin{array}{l}\text { A big fowl } \\
\text { un gros coq }\end{array}$ & $\begin{array}{l}\text { A big fowl } \\
\text { un gros coq }\end{array}$ \\
\hline 3 & $\begin{array}{l}3 \text { big tubers of yam } \\
\text { Quatre grandes tubercules d'Igname }\end{array}$ & $\begin{array}{l}\text { Eight big tubers of yam } \\
\text { Huit grandes tubercules d'Igname }\end{array}$ & $\begin{array}{l}\text { Eight big tubers of yam } \\
\text { Huit grandes tubercules d'igname }\end{array}$ \\
\hline 4 & $\begin{array}{l}\text { giant he- goat (apirapi) } \\
\text { Une géante chèvre }\end{array}$ & $\begin{array}{l}\text { 1 giant he- goat (apirapi) } \\
\text { Une géante chèvre }\end{array}$ & $\begin{array}{l}\text { I giant he- goat (mpimpi ewu) } \\
\text { Une géante chèvre }\end{array}$ \\
\hline 5 & $\begin{array}{l}\text { Eight Igbo kola nuts } \\
\text { Huit noix de kola }\end{array}$ & $\begin{array}{l}\text { Eight Igbo kola nuts } \\
\text { Huit noix de kola }\end{array}$ & $\begin{array}{l}\text { Eight Igbo kola nuts } \\
\text { Huit noix de kola }\end{array}$ \\
\hline 6 & $\begin{array}{l}\text { Six heads of Tobacco } \\
\text { Les tabacs }\end{array}$ & $\begin{array}{l}\text { Four heads of tobacco } \\
\text { les tabacs }\end{array}$ & $\begin{array}{l}\text { Four heads of tobacco } \\
\text { les tabacs }\end{array}$ \\
\hline 7 & $\begin{array}{l}\text { One bottle of St. Remi dry gin } \\
\text { Une bouteille de st. Remi }\end{array}$ & $\begin{array}{l}\text { two bottles of St Remi dry gin } \\
\text { deux bouteilles de St Remi } \\
\text { deux boutteilles of St Remi dry gin }\end{array}$ \\
\hline 8 & Snuff (utaba egwere egwe) le tabac à priser & Snuff (utaba egwere egwe) le tabac à priser \\
\hline $\begin{array}{l}\text { Snuff (utaba egwere egwe) } \\
\text { le tabac à priser }\end{array}$ \\
\hline
\end{tabular}

Group B: List for Umuada (Kindred Daughters)

\begin{tabular}{|c|c|c|c|}
\hline & Uga & Amawbia & Enugu Agidi \\
\hline 1 & $\begin{array}{l}\text { Five creates of Maltina } \\
\text { Cinq casiers de boisson Maltina }\end{array}$ & $\begin{array}{l}\text { Six creates of Maltina } \\
\text { Six casiers de boisson Maltina }\end{array}$ & $\begin{array}{l}\text { One create of Guinness } \\
\text { malt. } \\
\text { un casier de boisson } \\
\text { Guinness malt. }\end{array}$ \\
\hline 2 & $\begin{array}{l}2 \text { cartons of truck soap } \\
\text { ( } 60 \text { bars) } \\
\text { (deux cartons de savon de marque truck } \\
\text { (soixante tablettes) }\end{array}$ & $\begin{array}{l}2 \text { cartons of truck soap } \\
\text { (60 bars) } \\
\text { (deux cartons de savon } \\
\text { De marque truck } \\
\text { (soixante tablettes) }\end{array}$ & \\
\hline 3 & $\begin{array}{l}2 \text { Rolls of Lux Soap } \\
\text { vingt quatre savon de marque lux } \\
\text { (vingt quatre rouleaux) }\end{array}$ & $\begin{array}{l}2 \text { Rolls of Lux Ssoap } \\
\text { vingt quatre savon de marque lux } \\
\text { (vingt quatre rouleaux) }\end{array}$ & \\
\hline 4 & 2 packets of cabin biscuits & . 4 packets of cabin biscuits & \\
\hline
\end{tabular}




\begin{tabular}{|l|l|l|l|}
\hline & $\begin{array}{l}\text { Deux paquets de biscuits } \\
\text { Cabin }\end{array}$ & $\begin{array}{l}\text { Deux paquets de biscuits } \\
\text { Cabin }\end{array}$ & \\
\hline 5 & $\begin{array}{l}\text { A cash of (\# 3000) three thousand naira } \\
\text { Une somme de trois mille naira }\end{array}$ & $\begin{array}{l}\text { A cash of (\# 3000) three thousand naira } \\
\text { Une somme de trois mille naira }\end{array}$ & \\
\hline
\end{tabular}

\section{Group C: Alutaradi (Kindred Women)}

\begin{tabular}{|l|l|l|l|}
\hline Uga & Amawbia & Enugu agidi \\
\hline 1 & $\begin{array}{l}3 \text { creates of Maltina } \\
\text { Trois casiers de boisson maltina }\end{array}$ & $\begin{array}{l}\text { Four creates of Guiness malt } \\
\text { Quatre casiers de } \\
\text { boisson Guinness malt }\end{array}$ & $\begin{array}{l}\text { Four creates of Guiness malt } \\
\text { Quatre casiers de } \\
\text { boisson Guinness malt }\end{array}$ \\
\hline 2 & $\begin{array}{l}2 \text { cartons of Bar soap } \\
\text { Quatre cartons de savon } \\
\text { deux cartons de savon Truck }\end{array}$ & $\begin{array}{l}\text { A cash of (N, 1500) one thousand five hundred } \\
\text { Naira only. } \\
\text { Un argent liquide de mille cinq cents Naira }\end{array}$ \\
\hline 3 & $\begin{array}{l}2 \text { rolls of lux soap ( 24 tablets ) } \\
\text { Deux rouleaux de savon lux } \\
\text { (vingt quatre tablettes) }\end{array}$ & $\begin{array}{l}2 \text { rolls of lux soap ( 24 tablets ) } \\
\text { Deux rouleaux de savon lux } \\
\text { (vingt quatre tablettes) }\end{array}$ & \\
\hline $4 \begin{array}{l}2 \text { packets of cabin biscuit } \\
\text { deux paquets de biscuits Cabin }\end{array}$ & $\begin{array}{l}\text { 6 packets of Cabin biscuit } \\
\text { six paquets de biscuits cabin }\end{array}$ & \\
\hline 5 & $\begin{array}{l}\text { A cash of (N 2, 000) two Thousand naira only. } \\
\text { Une somme de deux mille naira. }\end{array}$ & $\begin{array}{l}\text { A cash of (N 1, 000) one Thousand naira only. } \\
\text { Une somme de mille naira. }\end{array}$ & \\
\hline
\end{tabular}

Group D: Umuagbogho (Kindred Girls)

\begin{tabular}{|c|c|c|c|}
\hline & Uga & Amawbia & Enugu Agidi \\
\hline & $\begin{array}{l}2 \text { creates of Maltina } \\
\text { Deux casiers de maltina }\end{array}$ & $\begin{array}{l}4 \text { creates of Maltina } \\
\text { Quatre casiers de maltina }\end{array}$ & $\begin{array}{l}4 \text { creates of guiness malt. Quatre casiers de boisson } \\
\text { guiness malt }\end{array}$ \\
\hline & $\begin{array}{l}1 \text { carton of truck soap ( } 30 \text { bars) } \\
\text { Un carton de savon truck( trente tablettes) }\end{array}$ & \begin{tabular}{|l|}
1 carton of Truck soap ( 30 bars) \\
Un carton de savon truck( trente \\
tablettes) \\
\end{tabular} & $\begin{array}{l}8 \text { bars of soap } \\
\text { Huit barres de savon }\end{array}$ \\
\hline & $\begin{array}{l}4 \text { packets of cabin biscuit } \\
\text { Quatre paquets de biscuits cabin }\end{array}$ & $\begin{array}{l}2 \text { packets of cabin biscuit } \\
\text { Deux paquets de biscuits cabin }\end{array}$ & $\begin{array}{l}6 \text { packets of cabin } \\
\text { biscuits. } \\
\text { Six paquets de biscuits cabin } \\
\text { de biscuits cabin } \\
\end{array}$ \\
\hline & \begin{tabular}{|l|}
2 rolls of lux ( 24 tablets) \\
Deux rouleaux de savon lux(vingt quatre \\
tablettes de savon lux.)
\end{tabular} & $\begin{array}{l}4 \text { rolls of lux } \\
\text { Quatre rouleaux de savon lux } \\
\text { savon lux }\end{array}$ & $\begin{array}{l}4 \text { rolls of lux } \\
\text { Quatre rouleaux de savon lux } \\
\text { savon lux }\end{array}$ \\
\hline & $\begin{array}{l}1 \text { big Morning rose powder } \\
\text { la plus grande poudre de Morning rose. }\end{array}$ & $\begin{array}{l}1 \text { big Morning rose Powder } \\
\text { la plus grande poudre de Morning rose } \\
\text { Morning rose }\end{array}$ & $\begin{array}{l}1 \text { big Morning rose Powder } \\
\text { la plus grande poudre de Morning rose } \\
\text { Morning rose }\end{array}$ \\
\hline & $\begin{array}{l}6 \text { A cash of }(N 1,000) \text { one } \\
\text { thousand naira } \\
\text { Une somme de mille naira } \\
\end{array}$ & $\begin{array}{l}\text { A cash of ( } N \text { 2000) two thousand naira } \\
\text { only. Une somme de deux mille naira } \\
\text { seulement }\end{array}$ & $\begin{array}{l}\text { A cash of ( } N 600 \text { ) Six hundred naira only. } \\
\text { Une somme de six cents naira seulement }\end{array}$ \\
\hline
\end{tabular}

Group E: Umuokorobia (Kindred boys)

\begin{tabular}{|c|c|c|}
\hline Uga & Amawbia & Enugu Agidi \\
\hline $\begin{array}{l}\text { NB: } \\
\text { Uga kindred boys are attached to their kindred } \\
\text { men to share their items. No separate items for } \\
\text { Uga kindred boys. }\end{array}$ & $\begin{array}{l}\text { Six packets of cigarettes } \\
\text { Two cartons of stout and two cartons of } \\
\text { Gulder } \\
\text { Six paquets de cigarettes. Deux cartons } \\
\text { de biere : Stout et Gulder } \\
\text { respectivement. }\end{array}$ & $\begin{array}{l}\text { Four packets of Benson and Hedges, two } \\
\text { bottles of Gulder ,two bottles of Stout. } \\
\text { Quatre paquets de cigarette, Benson \& Hedges., } \\
\text { deux bouteilles de bière Gulder, deux bouteilles } \\
\text { de bière Stout. }\end{array}$ \\
\hline
\end{tabular}

The items in the three towns are virtually the same. What differs is the number demanded of those items to be brought. In Igbo land, children are collective responsibilities. Children are not owned by one person or being trained by only their biological parents. Everybody from the kindred will ensure the success of one's child, thus justifying the Igbo saying that "Nwa bu Nwa ora" / A child belongs to everybody". The different soaps in the list are shared by women.

\subsection{Data analysis}

In this section, some of the gift items in Igbo land are selected, their equivalents in French are given but where the items 
do not exist in French culture translation of those items are made, Also their significances are discussed. The items, given to each group, suit their age. For example cigarette is not in included in the list for men because they are old instead it is meant for the kindred boys. Powder is given to neither kindred daughters nor kindred women because they are already married but to kindred girls who are still praying for their husbands respectively.

\begin{tabular}{|l|l|l|l|}
\hline & ITEMS IN ENGLISH & FRENCH & SIGNIFICANCE \\
\hline 1 & A big fowl. & Un gros coq & Strength, honour, recognition. \\
\hline 2 & Tubers of yam. & Les ignames & Unity, covenant between two families. \\
\hline 3 & Igbo kola nut. & Noix de kola d'origine igbo. & Welcome, peace, acceptance. \\
\hline 4 & Snuff. & Le tabac à priser & Economic purposes. \\
\hline 5 & Giant he-goat & Une géante chèvre & Multiplication power. \\
\hline 6 & Jars of palm wine & Un bidon de vin de palme & Prosperity, lasting, progress in life \\
\hline 7 & Heads of tobaco & Les tabacs & Gains, profits, savings \\
\hline 8 & $\begin{array}{l}\text { Alligator pepper (ose } \\
\text { ora) }\end{array}$ & Les plus petits poivres & $\begin{array}{l}\text { To remove shame, for cleansing. Anytime it is used in marriage, the marriage must } \\
\text { stand. There is a saying in igbo language that ose ora anaghi eje ije ihere. Alligator } \\
\text { pepper cannot attract shame. }\end{array}$ \\
\hline 9 & St. Remi/ Schnapps & Gin de St. Remi/Schnapps & Union between the dead and the living \\
\hline 10 & Hen & Une poule & Fertility \\
\hline 11 & Beer & $\begin{array}{l}\text { Des bières/ beaufort flag } \\
\text { béninois }\end{array}$ & Acculturation. They are foreign items now used for entertainment \\
\hline 12 & Crates of Maltina & Cassiers de boisson, Maltina & Acculturation \\
\hline 13 & Bars of soap & Pain de savon & Beautification and purification \\
\hline 14 & Biggest morning Rose & $\begin{array}{l}\text { La plus grande poudre de } \\
\text { morning Rose }\end{array}$ & Beautification. In the olden days, they use ufie or nzu ka olin \\
\hline
\end{tabular}

\section{Conclusion}

The discussion has shown that meaning attached to objects is done by a group of people and when that is established it becomes part of their culture.

So it is in the interpretation of gift items presented as condition for marriage in certain communities in Igbo land. For example kola is found everywhere in Africa. Some people see it as an ordinary fruit seed with less importance but for the Igbo, it is the highest gift to offer one's visitors. That is why there is a saying that the Hausa plant Kola but the Igbo celebrate Kola. In every event in Igbo land from child birth to death, there must be Kola. It is very significant in any ceremony which one performs in Igbo land without which the ceremony will not go on. A French man will give you wine or cheese in place of Kola. The tablets of Bar soap and Lux soaps are the highest quality of soaps found in the olden days. Every Kindred woman will joyfully collect hers as a token of the urine and feaces of the bride they partook in cleansing when she was a toddler. Such is not found in the French culture. Schnapps, a hot drink is used in pouring libation and in communicating with the ancestors. The Igbo believe strongly in ancestors and must pour some hot drink on the ground not on a cemented floor so that the ancestors will take their own share and bless the marriage. The different gift items represent the Igbo cultural Values.

\section{References}

Barthes, R (1967). Elements of Semiology, (trans. Annette Lavers \& Colin Smith. London: Jonathan Cape.

Baudrillard, J . \& Poster, M.(1988). Selected Writings, Cambridge. Polity Press.

Eco, U (1976). A Theory of Semiotics, Bloomington, IN: Indiana University Press.

Gocharenko, S.F.(1981) "la mission du traducteur: aujourd'hui et demain" Ixe Congres mondial de la FITI, Varsovie.

Hoof, H.V. (1989) Traduire l'anglais. Paris, Edition Duculot.

Mbiti, J.(1975). Introduction to African Religion, Nairobi: East African Educational Publishers.

Okon, B. et al .(2013). "Documenting the Significance of the Ibibio Traditional Marriage Gift Items: A Communicative Approach", WALC/LAN Conference, University of Ibadan, Ibadan.

Pierce, C.S. (1931- 58). Collected Writings (8 Vols), ( Ed. Charles Hartshome, Paul Weiss \& Arthur W. Burks). Cambridge, M. A Harvard University press.

Saussure, F. de. (1983). Course in General Linguistics (trans. Roy Harris), London: Duckworth.

Taylor J. (1963) Christian Presence and African Religion. Nairobi: Action Publisher.

Nida, Eugene, A, \& Charles R. Taber(1969). The Theory and Practice of Translation, With Special Reference to Bible Translating, Leiden: Brill.

Nida, Eugene(1964) Towards a Science of Translation. Leiden: E.J. Briu .

Waruta, D.W. (2005). Marriage and Family in Contemporary African Society. Nairobi: Action Publisher. 